\title{
Long-term outcome of unreamed intramedullary nails in femur diaphyseal fractures
}

\author{
Femur cisim kırıklarında oymasız intramedüller çivi uygulamasının \\ uzun dönem sonuçları
}

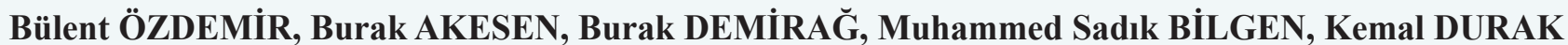

\section{BACKGROUND}

We evaluated the results of patients with traumatic femur diaphyseal fracture who had undergone biologic fixation with unreamed intramedullary nailing.

\section{METHODS}

Twenty-five adults with 29 traumatic femur diaphyseal fractures who had undergone unreamed intramedullary nailing at Uludag University School of Medicine, Department of Orthopedics and Traumatology were included in the study between January 1997 and December 2007. Gender, age, cause of injury, fracture type, operation length, time lapse till surgery, blood loss, fluoroscopy duration, early and late complications, time until union, and functional results were noted. Functional results were evaluated with Klemm-Börner and Thoresen systems and Short Form (SF)-36 health survey questions.

\section{RESULTS}

The mean follow-up of the patients was $65.1 \pm 31.6$ months (26-138). There was no statistically significant difference between operation length, blood loss and time until union of simple and complex fractures $(\mathrm{p}>0.05)$. Furthermore, the SF-36 questionnaire revealed no statistically significant difference between pain scores $(\mathrm{p}>0.05)$.

\section{CONCLUSION}

Sparing of the endosteal and periosteal circulation, low infection and high union rates, and good functional outcomes of unreamed intramedullary nailing fixation make it the treatment of choice for simple and comminuted fractures of the femur shaft, especially for multi-trauma patients and patients with cardiopulmonary comorbidities.

Key Words: Biologic fixation; femur shaft fractures; unreamed intramedullary nail.

\section{$\boldsymbol{A M A C}$}

Travmatik femur cisim kırı̆̆ı tanısı nedeniyle oymasız kilitli intramedüller çivi (İMÇ) kullanılarak biyolojik tespit yapılan hastaların sonuçları değerlendirildi.

\section{GEREÇ VE YÖNTEM}

Uludağ Üniversitesi Tıp Fakültesi Ortopedi ve Travmatoloji Anabilim Dalı'nda, Ocak 1997 - Aralık 2007 tarihleri arasında travmatik femur cisim kırığı tanısı ile oymasız kilitli İMÇ kullanılarak biyolojik tespit yapılan 25 (29 kırık) erişkin hasta çalışmaya dahil edildi. Olguların yaş ve cinsiyetleri, yaralanma nedenleri, kırık tipleri, ameliyata alınma zamanları ve ameliyat süreleri, kanama miktarları, skopi kullanım süreleri, erken ve geç dönem komplikasyonları, kaynama zamanı ve fonksiyonel sonuçları değerlendirildi. Fonksiyonel sonuçlar Klemm-Börner, Thoresen sistemi ile SF-36 genel sağlık anketi kriterlerine göre değerlendirildi.

\section{BULGULAR}

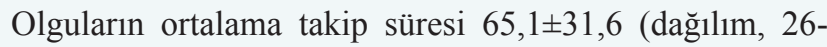
138 ) ay idi. Basit ve kompleks kırıklar arasında ameliyat süresi, kanama miktarı ve kaynama süresi açısından anlam11 fark olmadığg saptandı ( $p>0,05)$. SF-36'ya göre ağrı skorları arasında anlamlı fark saptanmadı $(\mathrm{p}>0,05)$.

\section{SONUÇ}

Femur cisminin basit ve çok parçalı kırıklarının oymasız İMÇ ile tespiti; endosteal ve periosteal kan dolaşımını bozmaması, derin enfeksiyon riskinin az olması, yüksek kaynama oranı ve fonksiyonel sonuçlarının iyi olması nedeniyle özellikle çoklu yaralanmalı, pulmoner ve kardiyovasküler riskleri olan hastalarda tercih edilmesi gerektiği sonucuna varılmıştır.

Anahtar Sözcükler: Biyolojik tespit; femur cisim kırığ1; oymasız kilitli intramedüller çivi. 
Diaphyseal fractures of long bones have been the most common fractures in orthopedics and traumatology. Increases in motor vehicle accidents, workrelated accidents and sport and gunshot injuries have also led to an increase in fractures of the femur and tibia in young individuals. ${ }^{[1]}$ To date, choice of treatment in femur diaphyseal fracture has been surgical. ${ }^{[2-4]}$ Conservative treatment of these fractures may disturb patient-physician relations due to serious systemic complications, decrease in range of motion in knee and hip joints, malunion, and nonunion. Furthermore, any attempt to treat these fractures conservatively can cause medico-legal problems. ${ }^{[4]}$

Recently, biologic fixation techniques for long bone fractures have gained in popularity. ${ }^{[5,6]}$ External fixation, plate-screw systems and intramedullary nails (IMNs) can be used for this purpose. ${ }^{[7,8]}$ However, locking IMNs have been the first choice in treatment of both open and closed femur and tibia fractures. ${ }^{[9,10]}$ IMNs can be used reamed or unreamed depending on the indication. However, local and systemic negative effects of reamed IMNs should be taken into consideration. Reaming has been blamed for disrupting the cortical blood flow, causes thermal necrosis of the cortical bone and results in marrow embolization, which may be a trigger for acute respiratory distress syndrome (ARDS). ${ }^{[11,12]}$ Unreamed IMNs are believed to have a less negative effect on bone blood supply. However, this topic is still controversial.

In this study, our aim was to present the outcome of femur diaphyseal fractures treated with unreamed IMNs with a minimum of two years of follow-up.

\section{MATERIALS AND METHODS}

From January 1998 through December 2007, 25 individuals who suffered 29 femur diaphyseal fractures and were treated with unreamed IMN were identified. Patients' records and radiologic surveys were reviewed for patient demographics, fracture type, type of surgical approach, associated injuries, and any complications related to treatment. At the patients' first presentation to the emergency room, all fractures were initially treated with long leg cast covering the ankle, knee and hip joint to the posterior superior iliac crest.

Fractures were classified according to $\mathrm{AO} / \mathrm{ASIF}$, and Gustilo-Anderson classification was used in case of open fracture. ${ }^{[13,14]}$ Unreamed IMNs (unreamed femoral nail, Synthes GmbH, Switzerland) were applied to each case under general or regional anesthesia. Patients were placed in the prone position. A lateral incision was carried from the trochanter major to $6-8 \mathrm{~cm}$ proximal. Following blunt dissection, the piriformis fossa was reached. The appropriate nail size was determined with measurements from the intact and the fractured side under fluoroscopy. Nail size was determined in bilateral fractures after closed reduction of the fracture. All nails were locked statically at the proximal and distal ends.

Open fractures were treated initially with aggressive debridement and irrigation with 4 to 5 liters sterile saline with added antibiotic. Surgical tools and drapes were then changed in order to avoid contamination. Then, unreamed IMN application was performed in the same scene. Tetanus prophylaxis was given to all patients. Pre- and postoperative antibiotic treatment was applied with first-generation cephalosporins and gentamicin for 24-48 hours.

Operation time and blood loss were measured. After follow-up radiographs suggested callus formation, full weight-bearing was allowed. Radiologic and clinical follow-ups were done at postoperative months 1 , 3, 6, and 12 and then annually. Radiologic union was accepted if callus formation was visible in at least three planes in anteroposterior and lateral radiographs and/or if the fracture line was no longer visible. ${ }^{[15]}$ Functional outcome was evaluated according to Klemm-Börner ${ }^{[16]}$ and Thoresen ${ }^{[17]}$ systems and Short Form-36 (SF-36). ${ }^{[18]}$

In our study, the Statistical Package for the Social Sciences (SPSS) 16.0 program was used for statistical analysis. Pearson chi-square test and Fisher's certain chi-square tests were performed for the analysis of categorical variables. Continues variables with normal distribution were analyzed using unpaired t-test, whereas variables that did not show normal distribution were analyzed via Mann-Whitney U test.

\section{RESULTS}

Of the 25 patients, $19(76 \%)$ were male and 6 $(24 \%)$ were female. Average age of the patients was $31.4 \pm 11.1$ years (range: $18-65$ ). Mean follow-up of the patients was $65.1 \pm 31.6$ months (range: $26-138$ ). There were 29 femur diaphyseal fractures in 25 patients who were treated with unreamed IMNs. The most common etiology of the fractures was motor-vehicle accident $(21 ; 84 \%)$, followed by fall $(3 ; 12 \%)$, and one suicide attempt (4\%). The majority of the fractures were simple 32-A type fractures in $19(65.5 \%)$ patients, with complex 32-B or 32-C type fractures in 10 $(34.5 \%)$ patients. Twelve patients suffered additional injuries (Table 1). According to Gustilo-Anderson, 1 patient had type 1, 1 patient had type 2, and 1 patient had type $3 \mathrm{C}$ open fracture. Close reduction and static locking were performed in all fractures. None of the patients suffered limited range of motion in knee or hip joints. The mean operation time for simple and complex fractures was $62.07 \pm 11.06$ minutes $(45-85)$ and 66.5 \pm 8.2 minutes (60-85), respectively ( $\mathrm{p}>0.05)$. Mean blood loss during the surgery for simple and complex fractures was $104.5 \pm 41.9$ and $116.8 \pm 48.3 \mathrm{ml}$, respectively $(\mathrm{p}>0.05)$. The average time for complete 
Table 1. Information about fracture types, additional injuries and follow-up of patients

\begin{tabular}{|c|c|c|c|c|}
\hline No & Age & $\begin{array}{l}\text { Fracture } \\
\text { type }\end{array}$ & Additional injury & $\begin{array}{l}\text { follow-up } \\
\text { (months) }\end{array}$ \\
\hline 1 & 24 & $32 \mathrm{~A} 3$ & & 64 \\
\hline 2 & 35 & $32 \mathrm{~B} 3$ & Spine fracture & 38 \\
\hline 3 & 30 & $32 \mathrm{~B} 1$ & & 44 \\
\hline 4 & 18 & $32 \mathrm{~A} 3$ & Acetabular fracture (same side) & 60 \\
\hline 5 & 30 & $32 \mathrm{C} 2$ & Fibula and spine fracture & 31 \\
\hline \multirow[t]{2}{*}{6} & 64 & $32 \mathrm{~A} 2$ & & \\
\hline & & $32 \mathrm{~A} 3$ & & 69 \\
\hline 7 & 20 & $32 \mathrm{~B} 1$ & & 56 \\
\hline 8 & 34 & $32 \mathrm{~B} 1$ & & 39 \\
\hline 9 & 32 & $32 \mathrm{~A} 2$ & & 40 \\
\hline \multirow[t]{2}{*}{10} & 26 & $32 \mathrm{~A} 3$ & & \\
\hline & & $32 \mathrm{C} 3$ & Tibia fracture & 112 \\
\hline 11 & 18 & $32 \mathrm{~A} 3$ & & 122 \\
\hline 12 & 36 & $32 \mathrm{~A} 3$ & Pelvis, acetabular, fibula fracture & 26 \\
\hline 13 & 23 & $32 \mathrm{~A} 2$ & & 55 \\
\hline 14 & 24 & $32 \mathrm{~A} 3$ & Malleolar fracture (same side) & 48 \\
\hline \multirow[t]{2}{*}{15} & 22 & $32 \mathrm{~A} 3$ & & \\
\hline & & $32 \mathrm{~A} 3$ & Pelvis fracture & 67 \\
\hline 16 & 33 & $32 \mathrm{~A} 3$ & & 138 \\
\hline 17 & 31 & $32 \mathrm{~A} 3$ & Humerus fracture & 30 \\
\hline 18 & 35 & $32 \mathrm{~A} 3$ & & 50 \\
\hline 19 & 27 & $32 \mathrm{~B} 1$ & Calcaneus fracture (same side) & 35 \\
\hline \multirow[t]{2}{*}{20} & 39 & $32 \mathrm{~A} 3$ & & \\
\hline & & $32 \mathrm{~A} 3$ & Tibia fracture (same side) & 73 \\
\hline 21 & 29 & $32 \mathrm{~A} 3$ & Humerus fracture & 114 \\
\hline 22 & 33 & $32 \mathrm{~B} 1$ & & 57 \\
\hline 23 & 41 & $32 \mathrm{~A} 2$ & & 125 \\
\hline 24 & 24 & $32 \mathrm{C} 3$ & & 48 \\
\hline 25 & 31 & $32 \mathrm{~B} 1$ & $\begin{array}{l}\text { Tibia, malleolar metatarsal fracture } \\
\text { (same side) }\end{array}$ & re 49 \\
\hline
\end{tabular}

union in simple and complex fractures was $3.7 \pm 0.9$ and $4.4 \pm 2.6$ months, respectively ( $>0.05$ ). There was nonunion in 1 patient with type-3C open fracture with femoral artery and vein injury. This nonunion was treated by reamed IMN and autograft from the iliac crest by minimal exposure of the fracture site. Three patients had $1 \mathrm{~cm}$ shortness in the lower extremity due to the fracture. Of these patients, 1 had $10^{\circ}$ varus deformity, 1 had $10^{\circ}$ valgus deformity and 1 had multipart fracture (Fig. 1).

Physical therapy was started on the postoperative 1st day, and patients started to mobilize with crutches the next day. Patients were allowed to mobilize with partial weight-bearing for six weeks. After follow-up radiographs suggested callus formation, full-weight bearing was allowed. Patients with additional injuries or bilateral fractures received physical therapy in their beds without weight-bearing and were allowed weight-bearing after completion of union.

Functional outcomes according to Klemm-Börner and Thoresen systems are summarized in Table 2. Average scores on the physical function scale of the SF-36 were 94 and 87.4 in simple and complex fractures, respectively $(\mathrm{p}>0.05)$. Average scores on the pain scale of the SF-36 were 99 and 97 in simple and complex fractures, respectively $(\mathrm{p}>0.05)$. Average scores on the SF-36 are given in Table 3.

\section{DISCUSSION}

The main goals of femur diaphyseal fracture treatment are as follows: maintenance of normal length and axis of the lower extremity, complete union, early mobilization, and maintenance of normal range of motion in knee and hip joints. ${ }^{[8,19,20]}$ Unreamed IMNs are appropriate fixation instruments for the long spiral, oblique, multi-part fractures of the femur as well as simple fractures above and below the isthmus. ${ }^{[20]} \mathrm{Op}$ eration time for fixing femur diaphyseal fractures with unreamed IMNs has been reported in the literature as between 50 and 140 minutes. ${ }^{[21,22]}$ Mean operation time
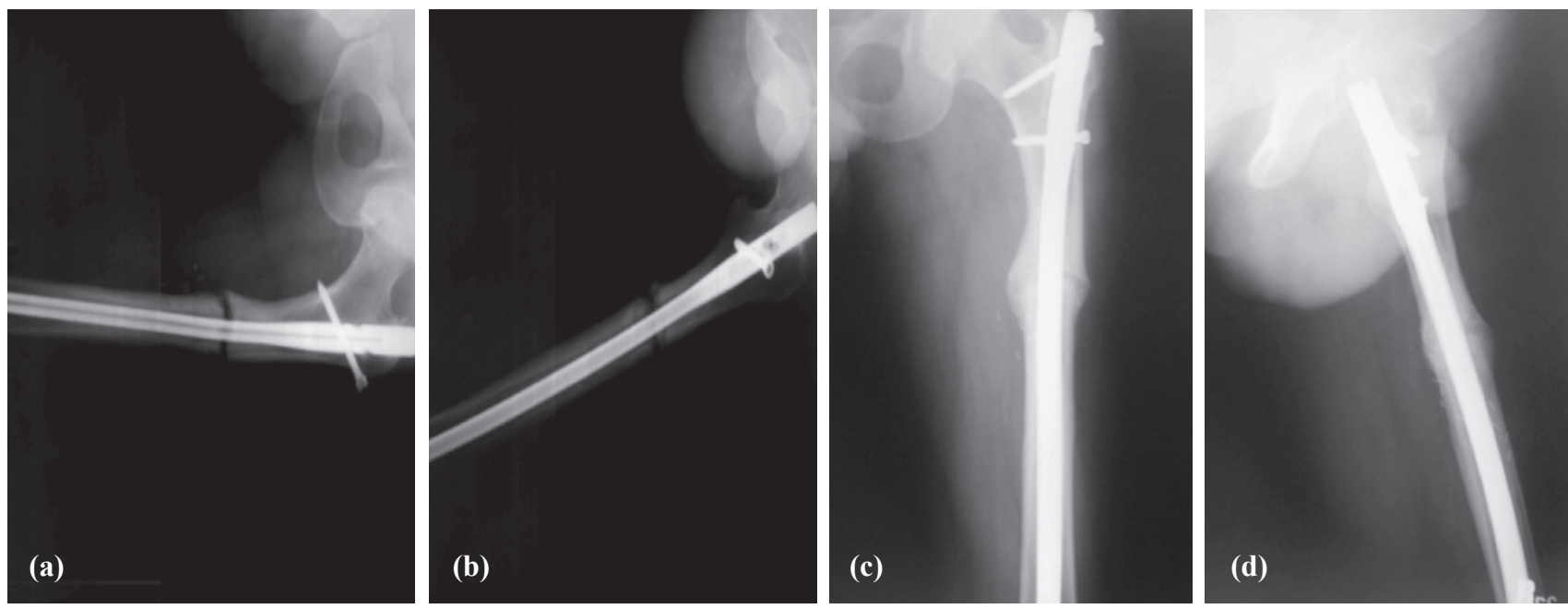

Fig. 1. (a, b) A 32-year-old man who suffered open femur diapyhsis fracture with accompanying femoral artery and vein injury. He underwent unreamed IMN treatement. However it was resulted as nonunion. (c, d) His unreamed IMN was replaced with reamed IMN. Union of three cortices can be seen on the radiographs obtained postoperative 1 year. 
Table 2. Functional outcomes of the patients

\begin{tabular}{lcccccc}
\hline & \multicolumn{2}{c}{ Klemm \& Börner } & & \multicolumn{2}{c}{ Thoresen } \\
\cline { 2 - 3 } \cline { 6 - 7 } & $\mathrm{n}$ & $\%$ & & $\mathrm{n}$ & $\%$ \\
\hline Very good & 23 & 79.3 & & 24 & 82.8 \\
Good & 5 & 17.2 & & 5 & 17.2 \\
Moderate & 1 & 3.5 & & - & - \\
Poor & - & - & & - & - \\
\hline
\end{tabular}

in the present study was 62 minutes. We believe that application of IMN without using a guidewire, closed reduction, and insertion of the unreamed IMN are the main reasons for the reduced operation time.

In this study, all unreamed IMNs were locked statically. Dabezies et al. ${ }^{[23]}$ reported that micromotion and rotation are limited with static locking, and length of the fracture is maintained as well. Cortical contact is minimal or absent in segmental and multi-part fractures. In this case, static locking is mandatory in order to maintain alignment between fracture parts, and to prevent shortening, angulation and rotation..$^{[1,8,15]}$ Brumback et al. ${ }^{[24,25]}$ reported a $10.5 \%$ rate of loss of reduction in their study. They stated that loss of reduction usually occurs within the first postoperative three weeks and that correction of the angulation and shortness is relatively easy if noticed early; otherwise, more complex revision surgery will be necessary. Winquist et al. ${ }^{[8]}$ found in their study that $2 \%$ of cases had shortening of more than $2 \mathrm{~cm}$. The authors claimed that if the contact area between the fracture parts is more than $50 \%$, shortening is unlikely and dynamic locking will be adequate. In our study, three patients had shortness in their affected lower extremity and two of them had angulation. None of these patients was affected functionally due to the shortening. We believe that good functional outcome can be attributed to locking the IMNs statically in the beginning and to dynamization after callus formation.
Table 3. Average scores of SF-36 scales

\begin{tabular}{lc}
\hline Scale & Score \\
\hline Physical function & 92.5 \\
Role-physical & 96.5 \\
Role-emotional & 86.2 \\
Vitality & 86.7 \\
Mental health & 86.2 \\
Social function & 93.5 \\
Bodily pain & 97.8 \\
General health & 85.9 \\
Physical function scale & 93.1 \\
\hline
\end{tabular}

Time for union with reamed IMNs has been reported in the literature as between 4.4 and 4.8 months. $[20,21,26]$ This period has been reported as 3.3 months and 4.5 months in the series of Reynders and Broos and Ertürer et al..$^{[1,21]}$ In the present study, the average time for union was 4.2 months, which is compatible with the literature. The rate of nonunion has been reported as from $0 \%-8 \%$ and from $1 \%-2 \%$ with unreamed and reamed IMNs, respectively. ${ }^{[22,27,28]}$ Drosos et al. ${ }^{[29]}$ reported that there is a high risk of nonunion if the gap between the fracture edges is $3 \mathrm{~mm}$ or more. In our study, one patient with type 3C open fracture had nonunion (Fig. 2). We believe this complication is related to severe soft tissue injury and loss of fracture hematoma due to open fracture rather than the fixation technique. In our opinion, the appropriate definition of a fracture is not only the disruption of integrity of the bony structures but the disruption of integrity of the soft tissue that results with fracture. As was discussed in the results, the nonunion case in our study was treated with re-nailing with reamed IMN and autograft placement into the fracture site, which is the standard choice of treatment in our institute.

Malunion is another potential complication of unreamed IMN fixation, with a rate ranging between $21 \%$ and $22.5 \%$ in the studies of Kempf et al. and Sjoberg
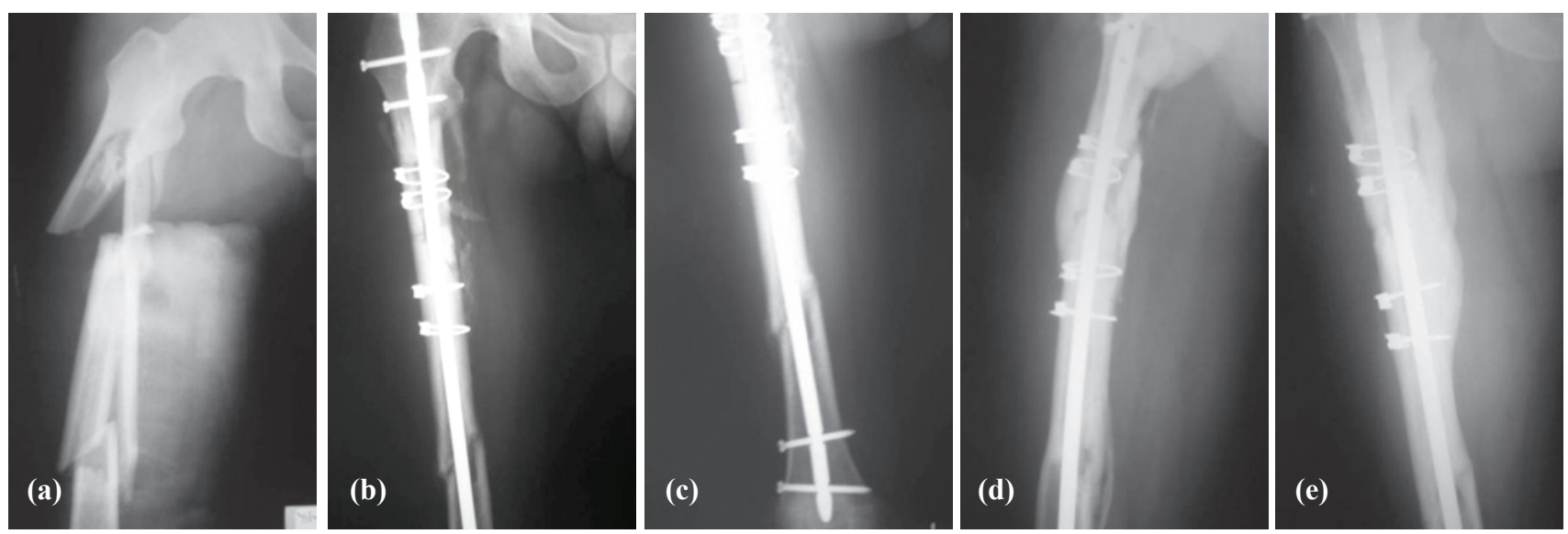

Fig. 2. (a) Complex fracture of femur (AO type 32-C) in a 24-year-old male after motor vehicle accident. (b, c) Immediate anterior-posterior and lateral radiographs after unreamed IMN. (d, e) Radiographs were obtained 20 months postoperatively. 
et al., respectively. ${ }^{[20,30]}$ In this study, two patients (8\%) had malunion with $10^{\circ}$ of angulation. We propose that the reason for this low rate of malunion compared to those two previous studies was strict adherence to the criteria of Krettek et al. ${ }^{[31]}$ to evaluate the axis of the fracture intraoperatively. There have been a limited number of studies about evaluating the functional outcomes after treatment of diaphyseal femur fractures. In our study, multiple outcome measures including Thoresen, Klemm-Börner, and SF-36 were utilized. Average scores of these instruments suggested very good or good functional results.

Although reamed IMNs have potential risks and complications and past studies have favored unreamed IMNs, these types of nails are not totally innocent. Unreamed IMNs are quick and simple to implant. However, unreamed IMNs are involved in more implant failures and require more second surgeries. ${ }^{[21,32]}$ Therefore, the decision of whether to use reamed or unreamed nails is still debated.

In a recent systematic review, Duan et al. ${ }^{[32]}$ reported that results of reamed IMNs are better compared to unreamed IMNs in terms of non/delayed union, and there was no significant difference between the two techniques according to mortality rate, implant failure, and ARDS. After reviewing the studies, the same authors stated that unreamed IMN is related to low blood loss.

In an experimental animal study, Högel et al. ${ }^{[33]}$ analyzed the rate of fat embolism in pulmonary arteries after both reamed and unreamed IMN application. They reported that IMN with reaming is a safe procedure and has less risk of pulmonary fat embolism. However, the size of the reamer they used was smaller than the original reamer designed by AO. They also concluded that the low rate of fat embolism may be associated with the narrow intramedullary canal of the sheep.

Our study includes the cases treated between 1998 and 2007. Unreamed IMN was the treatment of choice at that time, as reamed IMN was believed to be associated with the aforementioned risks and complications. However, in light of recent studies, reamed IMNs have also been used in our institute.

In conclusion, in addition to the selection of IMN type (reamed/unreamed), patient selection, evaluation of the fracture type, appropriate fixation technique, close follow-up of the patients, and most importantly, early rehabilitation and mobilization contribute to a good outcome.

\section{REFERENCES}

1. Ertürer E, Oztürk I, Dirik Y, Uzun M, Aksoy B. Radiographic and functional results of osteosynthesis with locked un- reamed intramedullary nailing of femoral shaft fractures in adults. Acta Orthop Traumatol Turc 2005;39:381-6.

2. Star AJ, Bucholz RW. Fractures of the shaft of the femur. In: Bucholz RW, Charles CMB, editors. Rockwood and Greens fractures of adults. Vol. 2., 6th ed. New York: Williams\&Wilkins; 2006. p. 1846-911.

3. Colton CL. The history of fracture treatment. In: Browner BD, editor. Skeletal trauma. 3rd ed. Philadelphia: Saunders; 2008. p. 3-28.

4. Whittle AP, George W, Wood II. Fractures of lower extremity. In: Canale ST, editor. Campbell's operative orthopaedics. Vol. 3. Philadelphia: Mosby; 2003. p. 2725-872.

5. Papakostidis C, Grotz MR, Papadokostakis G, Dimitriou R, Giannoudis PV. Femoral biologic plate fixation. Clin Orthop Relat Res 2006;450:193-202. CrossRef

6. Leunig M, Hertel R, Siebenrock KA, Ballmer FT, Mast JW, Ganz R. The evolution of indirect reduction techniques for the treatment of fractures. Clin Orthop Relat Res 2000;375:714. CrossRef

7. Perren SM. Evolution of the internal fixation of long bone fractures. The scientific basis of biological internal fixation: choosing a new balance between stability and biology. J Bone Joint Surg Br 2002;84:1093-110. CrossRef

8. Winquist RA, Hansen ST Jr, Clawson DK. Closed intramedullary nailing of femoral fractures. A report of five hundred and twenty cases. J Bone Joint Surg Am 1984;66:529-39.

9. Broos PL, Sermon A. From unstable internal fixation to biological osteosynthesis. A historical overview of operative fracture treatment. Acta Chir Belg 2004;104:396-400.

10. Finkemeier CG, Schmidt AH, Kyle RF, Templeman DC, Varecka TF. A prospective, randomized study of intramedullary nails inserted with and without reaming for the treatment of open and closed fractures of the tibial shaft. J Orthop Trauma 2000;14:187-93. CrossRef

11. Rüedi TP, Murphy WM. Intramedullary nailing. AO principles of fracture management. In: Krettek C, editor. New York: AO Publishing; 2000. p. 195-218.

12. Ürgüden $M$, Özdemir $H$, Yanat $A N$, İnanmaz E, Akyıldız FF, Altınel E. The problems encountered in the treatment of femoral fractures with locked intramedullary nailing. Acta Orthop Traumatol Turc 2001;35:418-29.

13. Anvar R, Tuson K, Khan SA. Classification and diagnosis in orthopaedic trauma. New York: Cambridge University Press; 2008. p. 157-88.

14. Olson S, Willis M. Initial management of open fractures. In: Bucholz RW, Charles CMB, editors. Rockwood and Greens fractures of adults. Vol. 2., 6th ed. New York: Williams\&Wilkins; 2006. p. 395.

15. Onder Kalenderer, Ali Reisoglu, Gurkan Eryanilmaz, Haluk Agus. The results of unreamed interlocking intramedullary nailing in long bone fractures. Acta Orthop Traumatol Turc 2000;34:260-6.

16. Ezirmik N, Keskin D, Karsan O, Öner Ş. The results of interlocking intramedullary nail applications in adult femoral shaft fractures. Journal of Arthroplasty and Arthroscopic Surgery 2002;13:174-81.

17. Thoresen BO, Alho A, Ekeland A, Strømsøe K, Follerås G, Haukebø A. Interlocking intramedullary nailing in femoral shaft fractures. A report of forty-eight cases. J Bone Joint Surg Am 1985;67:1313-20.

18. Keller SD, Bayliss MS, Ware JE Jr, Hsu MA, Damiano AM, Goss TF. Comparison of responses to SF-36 Health Survey questions with one-week and four-week recall periods. Health Serv Res 1997;32:367-84. 
19. Brumback RJ, Ellison TS, Poka A, Bathon GH, Burgess AR. Intramedullary nailing of femoral shaft fractures. Part III: Long-term effects of static interlocking fixation. J Bone Joint Surg Am 1992;74:106-12.

20. Kempf I, Grosse A, Beck G. Closed locked intramedullary nailing. Its application to comminuted fractures of the femur. J Bone Joint Surg Am 1985;67:709-20.

21. Reynders PA, Broos PL. Healing of closed femoral shaft fractures treated with the AO unreamed femoral nail. A comparative study with the AO reamed femoral nail. Injury 2000;31:367-71. CrossRef

22. Abbas D, Faisal M, Butt MS. Unreamed femoral nailing. Injury 2000;31:711-7. CrossRef

23. Dabezies EJ, D’Ambrosia R, Shoji H, Norris R, Murphy G. Fractures of the femoral shaft treated by external fixation with the Wagner device. J Bone Joint Surg Am 1984;66:3604.

24. Brumback RJ, Ellison TS, Poka A, Bathon GH, Burgess AR. Intramedullary nailing of femoral shaft fractures. Part III: Long-term effects of static interlocking fixation. J Bone Joint Surg Am 1992;74:106-12.

25. Brumback RJ, Uwagie-Ero S, Lakatos RP, Poka A, Bathon $\mathrm{GH}$, Burgess AR. Intramedullary nailing of femoral shaft fractures. Part II: Fracture-healing with static interlocking fixation. J Bone Joint Surg Am 1988;70:1453-62.

26. Giannoudis PV, Furlong AJ, Macdonald DA, Smith RM.
Reamed against unreamed nailing of the femoral diaphysis: a retrospective study of healing time. Injury 1997;28:15-8. CrossRef

27. Iacobellis C, Strukul L. Intramedullary nailing in femoral shaft fractures. Evaluation of a group of 101 cases. Chir Organi Mov 2008;92:17-21. CrossRef

28. Wolinsky PR, McCarty E, Shyr Y, Johnson K. Reamed intramedullary nailing of the femur: 551 cases. J Trauma 1999;46:392-9. CrossRef

29. Drosos GI, Bishay M, Karnezis IA, Alegakis AK. Factors affecting fracture healing after intramedullary nailing of the tibial diaphysis for closed and grade I open fractures. J Bone Joint Surg Br 2006;88:227-31. CrossRef

30. Søjbjerg JO, Eiskjaer S, Møller-Larsen F. Locked nailing of comminuted and unstable fractures of the femur. J Bone Joint Surg Br 1990;72:23-5.

31. Krettek C, Miclau T, Grün O, Schandelmaier P, Tscherne H. Intraoperative control of axes, rotation and length in femoral and tibial fractures. Technical note. Injury 1998;29:29-39. CrossRef

32. Duan X, Li T, Mohammed AQ, Xiang Z. Reamed intramedullary nailing versus unreamed intramedullary nailing for shaft fracture of femur: a systematic literature review. Arch Orthop Trauma Surg 2011;131:1445-52. CrossRef

33. Högel F, Gerlach UV, Südkamp NP, Müller CA. Pulmonary fat embolism after reamed and unreamed nailing of femoral fractures. Injury 2010;41:1317-22. CrossRef 